\title{
P16INK4a Negative Oropharyngeal Squamous Cell Carcinoma
}

National Cancer Institute

\section{Source}

National Cancer Institute. p16INK4a Negative Oropharyngeal Squamous Cell Carcinoma.

NCI Thesaurus. Code C147906.

An oropharyngeal squamous cell carcinoma which is negative for p16INK4a by immunohistochemistry. This negative immunohistochemistry result does not exclude human papillomavirus infection. 